\title{
The Socio-Cultural History, the Economic and Political Development of the Minority Society: The Case of Benishangul Gumuz (1991-2018)
}

\author{
Wondim Tiruneh Zeleke \\ Instructor \\ Department of Social Science \\ Injibara College of Teachers' Education, Ethiopia \\ E-mail: wondimzeleke@gmail.com
}

\begin{abstract}
The study focuses on the Socio-Cultural History and the Econo- Political Development of the Minority Society: The Case of Benishangul Gumuz(I99I-2018). The Gumuz of Matakal are renowned for their traditional socio-cultural history, economic and political developments since their arrival to Matakal. They have developed wonderful conflict management strategies and institutions that play important role in harmonizing their relations with the neighboring "ethnic" group, such as the Shinasha, Amhara, Agaw and Oromo. The conflicts differ in their causes, nature, intensity, frequency; yet the peculiarities are often glossed over and depicted as typical inter-ethnic conflicts between the highlanders or "settlers" on one side and the "indigenous "people on the other. Nonetheless, this approach not only risks a presupposition of ethnic groups as cohesive and binding entities but fails to explore the role of Gumuz initiation rituals, rite of passage, discourses of violence and other major socio-cultural events in inspiring and articulating them. So far, there exists no single comprehensive study, in its own right, that tries to map out the nexus between Gumuz perceptions, symbolism, representation and discourses of violence and outbreak of intermittent conflict in the region in time and space (I991-2018). The related literature will be systematically reviewed and relevant information gathered. Furthermore, in-depth interviews will be conducted, with elders from the highlanders, particularly from Amhara, Agaw, Shinasha, Oromo ethnic groups and the Gumuz. The data collected through these methods will be carefully examined, crosschecked, interpreted and analyzed to determine whether there will be any correlation or connection between the Gumuz, discourses of violence and outbreak of conflicts in the study area.
\end{abstract}

Keywords: Gunza,Ganza, Mussa Ceremony, Kanca Plots, Mangima Traditions.

\section{Introduction}

\section{I.I Geographical Setting}

The Mätäkäl Region of Western Ethiopia is a vast territory located in the north western Ethiopia, bordering the Republic of Sudan to the north of Blue Nile. It is bounded in the north by Gondar, in the south by Wälläga and Asossa, in the east by the former province of Gojjam, and the Sudan along the west( Berihun Mebratie ,1999;73). Before the Federal State structure, the region was also bounded by Begi-Meder and Semen, in the north, Qolla Dägä Damot in the north east, Sudan in the West, and Wälläga in the south/ Bogala Aligaz,20I3;I/.

Topographically, Mätäkäl Zone is extensively dominated by the low lying areas, with $74 \%$ flat plains, I6\% hilly and plateaus, 6\% valleys and the rest 4\% mountains area/ Mätäkäl Zonal Agricultural Department Office Report (Asossa, 2014,p.8).

Agro-ecologically, the region (Mätäkäl Zone) is divided into three major climatic zones in which qolla alone covers about 75\% (low lands below I,500masl), whereas Woina Däga accounts $24 \%$ ( Mid land between I,500-2,500 masl) and Däga accounts only a small amount, i.e, I\% highlands beyond 2,500 masl. Here, the temperature reaches about a daily maximum of $20^{\circ} \mathrm{c}$ to $25^{\circ} \mathrm{c}$ during the rainy season and rises to $35^{\circ} \mathrm{c}$ to $40^{\circ} \mathrm{c}$ in the dry season whereas the annual rain fall varies from 800 to $2000 \mathrm{~mm}$. Accordingly; the hottest period is from February to April. Therefore, the minimum daily temperature, depending on season and altitude, ranges from $12^{\circ}$ c to $20^{\circ}$ c(Beniŝangul-Gumuz Region Food Security Strategy,2004;5-6).

\section{I.2 Ethnographic Setting, Socio-Cultural Linkage and Economic Activity}

\section{I.2.I Early History}

In this sub topic, the myth and the origin of the Gumuz people, social organization, economic activity, settlement pattern and other related historical events to be discussed in brief and narrative evidences to be given in detail. 
As the myth of the origin of the Gumuz people is concerned, Wolde-Sellassie asserted that the Gumuz people, like other ethnic groups have their own traditional ways inorder to trace about their origin and development (Wolde-Sellassie Abbute,I984.). Furthermore, he also had forwarded the following illustrations by comparing the origin of the Gumuz with the genealogical line of other semetic language families:

"Once up on a time, twin sons were said to have born from a mother. One of the twin sons was black skinned (Gumuz) 'and the other was fair colored (non-Gumuz High Lander). They both grew up and matured, and then contested for power in the absence of a local assembly. At first; they both were given a horse for galloping. But the Gumuz fell down, while the highlander galloped well. Then they were offered to choose from bow and arrow on the one hand and spear and shield on the other. Then the Gumuz took the former and the non-Gumuz took the latter. Gradually, they were also made to choose from Inga (the Gumuz term for porridge) and Injera, where the Gumuz favored the former while the highlander favored the latter. Later they were asked to settle either to the right (in the Central highlands of Ethiopia) or to the left (towards the low lands of the periphery). From these two alternatives, the non-Gumuz chooses to settle to the right in the central highlands and the Gumuz choose to settle to the left towards the periphery/ Wolde-Sellassie ,Ibid/.

Therefore, the Gumuz claimed genealogically to have the inherited from the common descendant (ancestor) who was born as a twin from the same mother as their neighboring the non-black skinned highlanders. In the current Ethiopian regional administrative context, the Gumuz are a relatively populous however, powerless minority group inhabiting Mätäkäl Zone to the north as far as the shores of Lake Tana and Kamaśi Zone to the south of the Blue Nile River .Originally, their preferred settlement is in most case known to be a bush Savanna low land environment. Depending on their traditions, in the earlier times, they dwelled in the western part of the districts of Gojjam, where in the later times they were forced to have left the area by their strongest neighbors', both Amhara and Awi/ Wolde-Sellassie 2004,p.55/.

Mätäkäl region of Western Ethiopia may be regarded as the home of different minority ethnic identities and the site for cultural integration and interaction. Evidently, Gumuz, Sinaŝa, Awi, Oromo, and Amhara were/are still the most important population group who have continually been intermarried and being intermingling among themselves /Tsega Endalew,2006;p.I5/.

Depending on the accounts of travelers and local traditions, Tsega also states that the Mätäkäl region of Western Ethiopia was originally occupied first by the Gumuz and later by the Awi, Sinaŝa and the Oromo, who all began to live together around it. Hence, the Gumuz were/are the wide-spread and most numerous Koman branch in Ethiopia, who inhabited the area extends from near Metema on the border of Sudan south ward through Begemedir and Gojjam, and across the Blue Nile into the Deddesa Valley as far as the Leqemt Gimbi road/ Tsega Endalew,2006; Ibid/. They are believed to be the original inhabitants of Mätäkäl, North West of Gojjam. In the meantime, different settlers have arrived and settled in the region. For instance, the Sinaŝa, the Oromo, the Awi, the Amhara and other highland settlers. The distribution and uniformity of the language indicates a recent and an alarming expansion of the people in to their present large but less inhabited area /Tsega,Ibid/.

The Gumuz are also known as Gumis or Ganza, said to mean "Elders" in Gumuz language where as Gunza stands for "Man". As quoted in Taddesse, although the name "Gumuz" seems to be un known to the clans of Diddesa valley, the language is clearly the same as that of Begemedir and Gojjam , and as a cover name, "Gumuz" seems a reasonable choice/. Lionel Bender,1975;PP.6I-62/. For instance ,as stated above, the name Gumuz was not known to the clans of Didessa valley; so that they were nick named by the Gumuz of Mätäkäl as Begga, meaning "people”. Likewise ,the Gumuz of Quara and Mätäkäl were selectively called the tribe of" Shankilla' "where as those in Matama were also known as "Baria", in which both terms stands to mean the black. This generic and derogatory name is given for those dark skinned lowlanders by the non-Gumuz speaking people of the Nilo-Saharans/ Bogale Aligaz,2013;P.9/.

The population distribution of Mätäkäl is determined by the three major climatic zones in which Däga accounts about34\%, Woina Däga, 28\%, and qolla, 38\% respectively. In line with this, the land use category in the region is also estimated as forest land (79\%), cultivated land (7\%), cultivable land (7\%), and non-utilizable land (7\%)/ / Wolde-Sellassie Abbute,2002;p.3/.

\subsubsection{Socio-Cultural Linkage}

The total population of the Benishangul-Gumuz National Regional state based on the 2007 Population and housing census of Ethiopia, is estimated to be 784,345 , out of which members of the Gumuz ethnic group in the region numbered about $20.88 \%$. From this total, about 398,655 were males where as the rest 385,690 were females /Central Statistical Agency,2007 /. From the grand total stated above, at about I05,926 were urban inhabitants while the rest number has been covered by the rural inhabitants/Ibid/.

Depending on the present day administrative context, in most case, the Gumuz occupy Mätäkäl Zone to the north and Kamaśi Zone to south of the Blue Nile. As justification, Wolda-sellassie stated that the total population of Mätäkäl Zone is

${ }^{\text {I }}$ Shankilla/Baria, a derogatory name given for the black people by the highlander contendars. 
estimated to be 20I,52I, in which male being I0I,I34 and female I00, 387, of which I8I,9I4 are rural dwellers and I9,607are urban inhabitants(Wolde-Sellassie,2002;p.3).

Furthermore, he also described that the actual number of major ethnic groups in the regionisexpressedasGumuz(66,965),Amhara(47,900),SinaŜa(32,037),Oromo(27,050),Awi(I7,I 55),Kambata(2,875),Hadiyya(2 ,I79), Tigre(725),and in turn these all also composed of others/ Central Statistical Agency,2007 /.

In relation to population composition, the region has diverse ethnic groups in which five of them are believed to be early settlers to the area .Accordingly, these indigenous ethnic groups in their order of population number in the region are; Berta (26.7\%),Gumuz (23.4\%), Ŝinaŝa (7.0\%), Mao (0.6\%), and Komo (0.2\%). In addition to the natives, Tsegaye also indicated the significant numbers of other ethnic highlanders living in and around the region. For instance, Awi, Amhara, Oromo and others /Tsegaye Morada, 2013;p.4/.

\subsubsection{Traditional Religion}

Regarding religion, the population of the Beniŝangul Gumuz Region is Muslim (44.I\%), Orthodox Christian (34.8\%), Traditional religions (I3.1\%), Protestant Christian (5.8\%), Catholic (0.5\%), and other religions also account (I.5\%)/Tsegaye Morada, Ibid/. To the contrary, based on the 2007 population Census conducted by the Central Statistics Agency, there are variations in the number of ethnic groups who follow its own religion. For instance, the Muslim (44.98\%), Orthodox Christians $(33.3 \%)$, Protestant (13.53\%), and the rest $7.09 \%$ were said to have practiced traditional beliefs / Central Statistics Agency, $2007 /$.

Accordingly, spirit possession among the Gumuz women is said to be 'Zar' where as 'Gafea' stands for ritual specialists, animal sacrifice to 'Mussa' and 'Kemisa' stands for blessings as a part of death. However, those who are closest to Awi and Amhara neighbors topographically can exercise / follow the Christian faith where as those who are bordering the Muslim neighbor can attend the Islamic faith. Funeral ceremony is also done by females than males because of their suspect that when males look the dead, they may come to be cowards/ Informants: Yeshiwas Mamo, Zawdu Chakol and Balata Lakaw/.

Besides, most Gumuz tribes are still holding on to their traditional religion that is animism. Accordingly, they hold the belief that there is a higher god" Rebba", but what they mostly sacrifice is what we call "Mussa". Here, Mussa is being the spirit, which they believe, dwells in almost everything. The Gumuz also believe that "Mussa" is aggressive and can attack immediately if someone does wrong accordingly, what they believe is wrong .Furthermore, the Gumuz are animistic, which means they worship the'spirits' of certain rocks, trees, and animals for good health, good crops, good luck, and protection. But Rebba is their 'Supreme god who known as all' /Taressa, 20II; p.II/.

\subsubsection{Style of Marriage}

In Gumuz society, a family is the most crucial and basic social institution, where the husband, wife/wives, and children can form a family. The head of the family is the husband. Infants and small children are taken care closely by the mothers whereas grandparents and grandchildren form parts of the extended family. At any early stage, after the marriage of a junior wife, cowives usually share the same house. "The polygamy of the Gumuz is not the result of just on the part of the man, but of the women, who wish their husbands to have large families for the sake of the protection which many children give." / Alemayehu,2012;p.23/.

As stated by Jira, the Gumuz clans have lacked clearly marked/defined territories. They have been living in a dispersed manner because of the absence of defined territorial grouping. Looking the same clan or sub-clans who inhabited different territorial areas in the Gumuz history is common. For instance, there will be clans or sub-clans who are living within periodic environment from the same clan members/ Jira, 2008;P.48/. He also strongly argues that the social organization among the Gumuz is more evident at a village level where the origin of clan members traced their descent back to where their common lineage lived. In addition to the afro-mentioned information, the Gumuz of Mätäkäl has been re-arranged based on clan and territory/. Wolde-selassie ,2002;P.247/.In terms of Kinship, the Gumuz are organized in varies clans and sub-clans that comprise people who claim patrilineal descent relations.

In line with marriage and its style, Berihun states that the type of marriage exercised by the Gumuz is exogamous and polygamous exchange marriage where as the dwelling site for the newly married couples is patrilocal. He also generalizes that an intra-clan relations in the Gumuz land involve a limited area based on claims and co-operations / Berihun Mebratie ,2004;P.350/. The practical restrictions and obligations in which a clan member has to his fellow men are mainly related to marriage tie. In Gumuz socio-cultural history, a person is not allowed to marry an individual who has a claim with in the same clan ancestor as one's own/ Berihun ,2004/.

According to the baseline study commissioned by UNFPA on the prevention and management of gender- based violence in Ethiopia(2014), the following type of gender -based violence were prevalent in Beniŝangul Gumuz. These are forced marriage,

${ }^{2}$ Mussa, traditional religion, having the highest power of killing and curing. 
trafficking for sex, trafficking for labor, female genital mutilation, denying girls for the right to education, under eighteen sex work, and under fifteen sex abuse are the major violations for maternal and child health among the Gumuz girls /UNFPA,2014;P.5/.Similarly, Wolda-Selassie also categorizes the Gumuz marriage styles in to four major groups by supporting the oral informants where my focus group is evidently available in Jigda Sellassie ${ }^{3}$, a Gumuz village found in Mandura district. These are sister exchange, abduction, elopement, and marriage in the form of bride-wealth payment/ WoldeSellassie,2004;P.67/. Committing exogamous marriage from the same clan is impossible and hated throughout the Gumuz culture. Sister Exchange marriage, which is 'Manzikuma'/' angiya' in Gumuz language is the most important marriage type where the Gumuz people is practically implementing within their socio-cultural history. In this type of marriage, the bride groom offers his sister or daughter in the form of exchange to whom he is going to get marry /Wolde-Sellassie ,P.67/,

By contradicting the exchange marriage among the Gumuz of Mätäkäl, Wubat justifies that bride payment marriage is the most dominant and accepted marriage type than sister exchange marriage in Gumuz. For instance, in the Gumuz culture, a Gumuz girl can be exchanged for the sake of her brothers, fathers, uncles, or cousin' marriage /Wubat Engidayehu,2012;P.76 /. What makes different this type of marriage from the neighbor Awi is that in the latter case an Awi girl can be exchanged only for fulfilling the interest of her brother than her father, uncles or cousins'. This type of marriage among the Awi girls is practiced occasionally when one's parents do not have enough wealth to pay dowry/gift and a cluster of livestock that should be given for the newly engaged couples. Unlike the neighbors, for instance, Awi, the re-marriage of a widow with in the husband's kinship is the cultural evidence of the Gumuz/ Wubat ,2012,Ibid/.

Anybody having illicit relationships with some one's wife in the Gumuz culture leads to violence. If committed is a potential cause of conflicts unless the husband died. In this case, the wife of the deceased Gumuz is again assigned to be the wife of his brother or if no to be his relatives based on the male line tradition. However, as my informants narrated me in Mäntawuhä, sexual mating among the Gumuz women will be possible in hidden form but they may expose the event to their husbands deliberately/ Informants: Yeshiwas Mamo, Zawdu Chakol/.

Motivated by various actions, for instance, extra drink or whatever else, however, committing of adultery is one of the common causes of conflicts in the region. To make worse, it may advance to clan conflicts other than individual conflicts, as the husband of the abducted woman is poised to take revenge against he who committed adultery/ Informants: Yeshiwas Mamo, Zawdu Chakol/.

The assumption behind the inheritance marriage is probably preventing the destitution of widows, maintain women's status in the society, care and look after the born children and protect the wealth from non-relatives. In Gumuz culture, women commonly do not have the right to inherit properties in any case, whether from her family or from the death of her husbands or in case of divorce / Informants: Yeshiwas Mamo, Zawdu Chakol/.

In addition to this, all the properties brought during the time of marriage remains the personal/exclusive property of men. This is reasonably because of the belief of the society that the girls may be belonging to somebody else whenever possible. So that a Gumuz widow is supposed to be taken care of either by the husband's brother or a new relative who must be within the line of descendants of the male. In Gumuz Culture, weeding/engagement took place in market and virginity among the Gumuz girls have the highest social status/ Informants: Yeshiwas Mamo, Zawdu Chakol/.

Concerning the grown up children who lost their fathers, my informants described me that the property of the deceased individual will be inherited by his children while the widow will still marry her deceased husband's younger brother or one of his younger closest relatives as stated in the preceding pages. What should be understood here is that the Gumuz exercise the periodical transfer of rights of sexual access to a wife due to temporary absence of the husband for various reasons, for instance, long term imprisonment// Informants: Yeshiwas Mamo, Zawdu Chakol/.

In the Gumuz socio-cultural history, there is no any pressure that forced the Gumuz girls to get marriage earlier. When come to see the surrounding Awi girls comparing with the Gumuz, the former were forced to marry at the age of 9 to I2 years old while the latter never marry before the age of fifteen years / / Informants: Yeshiwas Mamo, Zawdu Chakol/.

Unlike the neighbor Awi, the sign / stage of maturing for marriage among the Gumuz is the girl's first menstrual experience. Surprisingly, the first menstruation of a young girl is celebrated with a joyful feast, chanting and singing. This event is believed that the first menstruation is the indication of maturity to become a woman// Informants: Yeshiwas Mamo, Zawdu Chakol/.

The practice of giving birth in the forest is a cultural belief to prevent family from curses. The Gumuz community believed that the curses are connected with women blood that occurs during menstruation and delivery. Therefore, during these two natural events, the women are expected to go to the forest, have their babies by themselves and leave the curse there/UNFPAp;;pp.6-7/.

Women stayed isolated for forty days even after delivery. It is believed that any blood seen in the house will lead to the anger of the house sprit, known as 'Musa misa'. If it happens, they ruin and change their houses and build some meters far away

${ }^{3}$ Jigda Sellassie, is a place name where, both a large number of Gumuz and some non-Gumuz people are living together. 
from the former. This is because their god' Musa' does not like to see any blood drop in the family. Hence, the woman will not have anything to do with family members until she is clean. At night, their husbands guard them from the danger of wild animals by camping some distances away from them/UNFPA,Ibid/.

The oral informants also generalize that tolerating the pain of delivery alone is said to be a mark of socially accepted value of the village women. For instance, those who fail to bear the pains before and during giving birth are ignored/ridiculed and shamed. Furthermore, touching the newly born baby except for the mother till the baby is one month old is forbidden in Gumuz culture. This is reasonably because, in Gumuz tradition, the newly born baby is still considered as sprinkled/contaminated by blood so that touching the baby may lead to death/ Informants: Yeshiwas Mamo, Zawdu Chakol and Balata Lakaw/.

Before the recent ten years, the Gumuz females unlike their male counterparts wear / cover their genital organs with skin of sheep or goat which is called 'Chicha' locally whereas the rest of their body is adorned / decorated with different sacrifice. They sometimes tie another cloth under their armpits for covering their breasts. Their cloth is named as 'Ticha', used as the only form of home -made cloth, especially used by women in order to cover their body near to the breast/bosoms. They also never like lying / denying whatever they committed wrong acts that violates the law of the country or traditional customary law/ Informants: Yeshiwas Mamo, Zawdu Chakol and Balata Lakaw.

\subsubsection{Settlement Pattern and Economic Activity}

As regards to the settlement pattern of the people under study, the works of many researchers and the oral accounts of the informants encouraged me to cross check about the type and the nature of settlement pattern how and where the Gumuz and other highlanders are living by neighboring one over another. Therefore, these and other related views have been indicated and detail narrations have been given below.

Before the arrival of re-settlers to Mätäkäl, the area was inhabited by an estimated indigenous Gumuz population of I8,3I2,who as the result of the re-settlers' arrival were replaced and forced to leave the area to the peripheries, being taken over of their native land resources that had served them as an extricable livelihood source/Wolde Sellassie,2002;P.5/.

The multi-ethnic composition in Mätäkäl comprised four sub- categories just to facilitate meaningful definition, where the first sub-group includes the indigenous Gumuz, who claim to be the first and original dwellers of Mätäkäl, Western Ethiopia. Whereas the second ethnic group, namely: Ŝinaŝa, Amhara (Gojjam/Begi Medir), Awi, and Oromo were lived neighboring each other for centuries/Wolde Sellassie,P.7/. The third ethnic group includes those spontaneous immigrant resettlers of the 1950s, who immigrated from north of Ethiopia resulted from food shortage following climatic changes, for instance, Amhara from Wollo. In the fourth place, those government sponsored re-settlers of the I980s are further re-divided in to diverse ethnic groups who evidently, inhabited Pawe Special Wäräda of the present day, Mätäkäl Zone/Ibid/.

As the ritual aspect of Gumuz agriculture is concerned, the informants conducted at Mäntawuhä and Mandura describe that the agricultural practice among the Gumuz people is of socio-cultural life and understood "far beyond immediate physical involvement and is inseparably interwoven with the beliefs in" "Fahsa", which is an ancestral spirit and "not merely an undertaking of the family or the group who are directly participating in the farming process by means of labor" / Informants: Yeshiwas Mamo, Zawdu Chakol and Balata Lakaw/.

Their farm used to be far from their villages which may take more than half an hour walk. Due to its distance, they do store the crops after harvest by building granary there. The task of women is bringing the crops from there every time to cook food for the family. To the contrary, the Gumuz men are only to be seen from the top (above all) as protectors looking for farm fields and preparing it for planting. Hunting of wild animals is also the day to day activity of the Gumuz men. In addition to the afro-mentioned duties, the Gumuz women start with the planting of crops and continue the work until the crop is ready for food or carrying to the market for cash/Taressa,20I I;PP.I3-I4/.

Within the cultural history of the Gumuz people, the ancestral and godly participation of agricultural activities take the form of blessings, and applying "Medicines" in order to increase the fertility of the plot land and to protect crops from any types of disaster/ Informants: Yeshiwas Mamo, Zawdu Chakol and Balata Lakaw/.

Oral informants, who are living together with the Gumuz also illustrates that the blessing rituals of crops have two dissimilar meanings, namely, Kemisa, meaning blessings as part of death where as the second blessing type is crop blessing ritual/ Informants: Yeshiwas Mamo, Zawdu Chakol and Balata Lakaw/. These blessing rituals are most significant to begin the farming season. Kemisa, a blessing ceremony practiced when a person has just passed away and its body is get ready for burial. Amusingly, varieties of crops are collected from all members of the residents and then put together for the blessing. Whereas the other form of blessing type that facilitates booming of productivity is related with the application of medicinal plants to the crop field and the seeds/Ibid/.In line with this, Dessalegn narrates that hunting of wild animals in the Gumuz land is connected with the use of different 'Biya'for each animal to hunt. Biya has also different applications based on the type of crops and its undertaking activity/Dessalegn Rahamato,I988;P.I27/. 
Agriculture is the main means of subsistence in the Gumuz society. The Gumuz people, who are believed to be the original inhabitants of Western part of Ethiopia, Mätäkäl, depend on a customary land tenure system of communal ownership. They are traditionally shifting cultivators who practice slashes and burn agriculture/Tsegaye,2013;P.5/. The practice of shifting cultivation by the Gumuz has often contradicted with pastoralism .However, the Gumuz are not actually pastoralists. Instead, they depend on shifting cultivation for their livelihood, which is supplemented with other subsidiary economic activities, for instance, hunting, gathering, fishing, honey production, collection and the extraction of minerals, like gold from the beach of the rivers. This makes the land as the most important resource of the economy and an integral part of the cultural life of the Gumuz/Tsegaye,2013/.

Dessalegn has also similar views with that of the Gumuz system of land holding system, which is owned communally. He also argues that "land", the most significant means of production is not private property but it is communal, and labor is carried based on association than individually. This communal labor association among the Gumuz is literally known as” Däbbo" or literally in Amharic as "Wabara" or literally in Awgni as "Wonfel”' Dessalegn Rahamato,1988/. In his view, the Gumuz people exercise different owner ship rights over various types of natural resources in which "all belong to the collective, with in the boundary of the clan". Based on this, he safely categorized the different resources of this clan model of collective ownership. Then, he indicates the two major divisions of Gumuz land in which each clan member has a right to use for cultivation or settlement purpose. Therefore, the property of a clan is at least three or four times greater than from those who are cultivating or ready to cultivate whenever possible/Dassalegn, $\mathrm{P} ; \mathrm{I} 25 /$.

The most important economic activity in Gumuz is shifting cultivation, in which locally known as "Malaya”, meaning "work" in the local language. The term is being applied in order to show where both work and agriculture in the Gumuz context are synonymous. Agricultural activities are mainly based on human labor, the use of the hoe (Berihun Makonnen,2009;PP.350$35 \mathrm{I}$ ). In the process of hoe cultivation, the Gumuz periodically shift (exchange) the agricultural plots. Unlike the High Landers, the Gumuz people do not cultivate their fields intensively. Evidently, plots which are cultivated for about three to four years will be left fallow for about six to ten years. After having done this, the Gumuz farmers clear and use new plots in every year and then leave fallow old one's for a certain period of time which in turn has adverse effect over the nature (Berihun Makonnen,P.35I).

In line with plotting lands in the Gumuz area, the oral accounts of the informants and the written works of Berihun together stated about the two major types of plots, also called Kanca and Bakuna land, where Kanca plots are newly and freshly cleared forest lands served to grow cereal crops, like millet as the main crop type in the intercropping farming practice (Berihun, ,2004;p.350). In the next year, Kanca plots are called 'jitank' and are sown with sorghum as the main crop. Generally, the Gumuz can be considered to be a good ethnographic justification for how people understood about shifting cultivation and how little evidence is significant on the socio-cultural history of the Gumuz people(Berihun,2004;PP.350-35I).

\section{Source of Conflict and Strategies how to handle Its Challenges 2.I Agitating factors for Gumuz Conflict}

In the Gumuz socio-cultural tradition, the males must give respect for the order of their wives. Because, in their tradition, the wives have had super power comparing with their husbands. Then, the husbands must full fill the responsibilities given by their wives. For instance, when the latters'ordered the formers' in order to kill the non-black Shoa men or a Gumuz enemy out of their clan, they must kill what they were told to do so(Informants : Qänaw Gobbäna, Wändäyä Bukrus,and Näni Wäzet).

Killing has given special value with in the Gumuz community in particular. They considered it as heroism. The black (Gumuz) who killed the red (non-Gumuz highlander) was considered as hero. For example, when the killer from the Gumuz side is died either through age or incidentally, special attention was given during mourning and his funeral was celebrated in special ceremonies and memorial figures were erected on their graves (Informants: Näni Wäzet, Wämpo Wägad, Zeguäfi Warb, and Megi Zelkaw).

Even worse, the killers must show their wives whom they killed by taking some parts of the body from the dead. For instance, the killers must show them by mutilating penis, the part of the genital organ. The killer has even given special admiration and prestige by the wife in particular and by the society in general. The killer also displaced the head of the deceased individual in the form of hat and also cutoff the arms and dried either by the scorching sun heat or smoke and finally served it to beat their drums during the memorial holidays (Ibid).

However, the one who he killed the female in their tradition never get respect from the society. It's even hated within their sociocultural history. Instead; the killer has given a nick name known as coward (Ibid).

\section{I.I Intra-Ethnic Conflict}

One of the causes that led to the intra-ethnic conflict among the Gumuz was adultery. This might happened when the young Gumuz has no sister for the exchange marriage or could not get wife or aimed at getting more than one wife. Both adultery and incest were the most hated traditions that became the first causing factors for the intra-clan conflicts within the Gumuz 
community. For instance, the husband whose wife was abducted either by the individuals within the same clan or out of the member caused to take retaliation against who committed adultery (Informants: Zewdu Chekol, Yeshiwas Mamo). When come to see the incest, it is strictly different from adultery in the case that the former stands for inter-breeding within the same line among the closest relatives where as in the case of the latter, the Gumuz individuals can commit it's sexual mating mostly with non-relatives. However, it does not mean that making adultery with the relatives is totally free. For example, as my oral informants discussed, the Gumuz young man who tried to obligate the young girl from his lineage for the purpose of sex may agitate killings by another relatives (Ibid).

Incidentally, when the conflict was suspended among the relatives due to adultery and incest, then the local people called this type of conflict as Manje Guşa $a^{4}$, in the local language meaning fire of sex, in order to indicate that the conflict was triggered by such events. Besides, adultery and incest, both belief in an evil-eye and the Gafia were also contributory factors for the intra-clan (ethnic) conflicts among the Gumuz community (Wolde-Sellassie,2004;P.240).

\section{I.2 Inter-Ethnic conflict}

The Inter-Ethnic conflict is the type of conflict where one group of clan is fricted against another clan out of the lineage. The most frequently occurred and dynamic causes of inter-ethnic conflicts between the Gumuz (Bega) and $\hat{S}_{u w a}$ (highland settler or Amhara) are the legacies of slave raids in the past(Wolde-Sellassie,P.244). In his turn, Aysheshim also summed that the ceaseless encroachment on the land resources of the Gumuz and the slave raiding campaign that victimized them has left (imprinted) bad legacies in their minds and created a deep- rooted enmity towards their neighboring highlanders (Aysheshim Madifu, I987;P.6I). Unlike the intra-ethnic conflict, the inter - ethnic conflict in the recent times is also caused by the following factors. Such as exchange marriage, bride price marriage, abducting girls, elopement, deliberate killings, resource use, insults, failure to pay back debts, and others(Informants: Yäŝ́éwas Mamo, Abdel Deboč, and Wändäyä Bukrus).

\subsection{Strategies How to Handle its Challenges}

As conflict mitigation mechanism is concerned, many researchers and scholars were used the terms like prevention, reconciliation, management and resolution in inter-changing manner. For instance, Tsega described conflict management as the part of theory and practice functionally facilitated for developing peaceful resolution for a given conflict which may result either from individuals or group based moves (Tsega Endalew, 2002; P.I4). It has ground rules based on the norms of a given society including reconciliation and arbitration where the strategy is above all led by the elders (by representing the society). These elders could use the systematic approach how to handle the two offending groups by allowing them to discuss in the round table and then find the solution after having understood their problems turn by turn(Informants: Adämu Endaläw, MäkonnänAgajie,and Assäfa Abäjéhu). It was also said that Miçu and Harma Hodha,the traditional institutions for peace building strategies have played a per amount role in the case of solving conflicts not only in between the Śinaśa and the Oromo but also among the different ethnic groups in the region namely; Awi, Amhara, Gumuz and others( Bogale Aligaz,2013;p.62).

The coming of Oromos in to Mätäkäl marked the development of both peace building strategies among the different ethnic groups in the region. Both institutions promoted smooth relationships among the members and then developed cultural tolerance and the commercial links when necessary. These institutions had multi modal services in the case that on the one hand it facilitated the relation and integration of the Śninaśa with other ethnicities such as in Dibaţé, Dängur, Bullän, and Wänbära areas and on the other hand, it played as the system of conflict mitigation strategy(Informants: Hänna Filäte, Tuji Erässo, and Qänaw Gobbäna).

The term Miçu is the Oromo term where the Gumuz also called Mangima, meaning friendly tie where they used for solving any problems occured in their community. Therefore, both communities used Miçu as a peace seeking strategy for conflict resolution to the disputes, enemity and conflicts that broke out among the different ethnic groups of the Mätäkäl region and its surroundings(Informants: Hänna Filäte, Tuji Erässo, and Qänaw Gobbäna). Miḉu (friendly tie) also known as "Wudaj” by theAwi natives refers to the most important strategy inorder to handle ethnic conflicts and establish an environment of tolerance and mutual coexistence among the ethnic groups in Mätäkäl(Informants: Mäkonnän Agajie, Mäkonnän Wolde Giorgis). During the Miçu institution, a ceremony is held in the institutional station where the contending groups slaughtered an animal and both groups were ordered to mix their blood to show complete friendship. Besides this, they break a bone to indicate, as they have broken their old quarrels. Finally, they swear an oath in order not deny each other, if either of them denies let his/her descendants be broken up to the last seven generations(Ibid).

Following the landing of Oromo population in Wänbära and Dibaţe since the Eighteenth century, the Oromos also developed the traditional conflict management institution called Luba Basa, literally meaning to make problems free. It was crucial in the case of solving the problems between the Gumuz and Oromo communities including the Śinaśa, particularly those who adopted the language of Oromiffa(Ibid).

${ }^{4}$ Maje Gusa, in the Gumuz language meaning fire of sex. 
In Mätäkäl, the Awi had traditional conflict resolution mechanism equally important with Miçu institution where the former can handle problems with the Gumuz, Oromo, Śinaśa and the Amhara. This traditional reconciling strategy among Awi is said to have called Wudaj,in Awgni language meaning, friend. In the case of Amhara, this institution is literally called Wadaj, similarly meaning friend. This $W_{a d a j}{ }^{5}$ system institution is the most important strategy in solving the problems created between Awi and the Gumuz in particular (Ibid).

Like other neighboring ethnic groups, the Gumuz have its own conflict management strategies above all lead by the elders. These Gumuz elders summon a meeting of their communities to negotiate the conflicting groups. They are skillful enough to resolve the problems where the rival bodies have presented the issues to them by seeking the solution accordingly. At the end, the elders set out compensation to be paid by the offender. No questions for the final decisions approved by the elders. Their decisions are accepted, and are seriously practiced (Fekadu Wamber ,I998;P.4) Similarly, Dessalegn also conceptualized that the Gumuz elders and leaders had the power of exercising their authority as the reconciliation effort is concerned .For instance, they have the power to punish those who stood against the traditional laws and customs of the Gumuz community(Dessalegn Rahamato,1988;P.19).

In addition to the elders, the Gumuz have also another traditional conflict reconciliation system known as Gafia. It is magico - religious authority exercised by the wizard where his or her action shows as if he/she would be a doctor and the protector of their community(Informants: Täddäsa Läma, Hänna Filäte, and Tuji Erässo).

Apart from this, it played to resolve the intra-ethnic conflict among the Gumuz with the coalition of the elders (Ibid). Equally with other institutions stated above, Siyaha system was also said to have applied in the Gumuz community where the elders were elected by the villagers where their Mangima $a^{6}$ assembly center was known as Tamba(Informants: Wändäyä Bukrus, and Aŝeber Woldu). Generally, Mangima (the Gumuz term for assembly), has been the most important traditional conflictresolution institution, particularly in solving the intra-clan (ethnic) conflicts and lineage level enemies among the Gumuz community in Mätäkäl(Informants: Abdel Deboč, and Qänaw Gobbäna).

\section{Methodology}

This article has developed based on both primary and secondary sources, where the primary sources are collected from the elderly individuals through interview. Here, focus group discussion was also vitally available with the Gumuz, Shinasha , Oromo, Awi and Amhara informants, who are living either together with the Gumuz or by neighboring them. The data for this study to be collected through interviews with elderly people based on their age nearest to the event in change and continuity, involving in both primary and secondary documents and from archives and publications focusing on the issue. The data collected through these methods would be carefully examined, cross-checked, interpreted and analyzed, to give meaningful justifications for the study.

Furthermore, the secondary sources are collected from periodicals, document analysis, Thesis dissertations, internet sources and other reports.

\section{Results and Discussions 4.IChanges and Continuities}

The declaration of the equality of peoples, nations and nationalities in 1994/5, paved the way for the birth of Minority Society in Ethiopia in general and the Gumuz people in particular. Before the advent of the Ethiopian Federal Democratic Revolution, the minority society was ignored from Social, Economic and Political aspects. For instance, there was no that much room for those who are black in skin color. Because, in some areas of Matakal, the Gumuz were not only socio-culturally hated but also they were deprived off any political fields (Informants: Ashebir Woldu, Yeshiwas Mamo).

For instance, the need for mutual economic integration and social ties between the Gumuz and the Highlanders widely expanded after the ratification of the Ethiopian new Constitution. Following the event, the ex- government appointees were politically ignored and the new Federal Government succeeded and re-distributed the land by taking extra and massive lands to the landless Gumuz peasants(Informants: Qanaw Gobbana, Dabasu Guk). When the re-distribution of rural land program came in to the reality, the highlanders, who are living by neighboring the Gumuz began to move towards the Gumuz land and tried to develop the degree of friendly relationship with the Gumuz, who owned the virgin land in the region of Matakal. Since then, many highlanders who either are agricultural investors who seasonally began to move in to the Gumuz lands searching for land lease or for the benefit of mutual crop sharing(Informants: Maku Baqala, Qanaw Gobbana).

The Gumuz came as the potential allies for the highlander land searchers, especially for the neighboring Agaws, who lost their hereditary land rights. Whereas the Gumuz, who emerged as the owner of the virgin land were not affected by land re-distribution following the state structure of the region. When the demand for land from the Agaws increased, the Gumuz

${ }^{5}$ Wadaj, has an equivalent meaning with friend particularly for the males.

${ }^{6}$ Mangima, is an assembly center where both rival groups are reconciling for actual peace rearranged by the elders both sides. 
virgin lands became the focal sights of the new agricultural lands(Informants: Lukundi Hatse.Maku Baqala).Although the situation is worse the Gumuz people are welcoming the seasonal and periodic advance of the highlanders, particularly Agaws and said to have created the socio-cultural links with them believing that they will be the beneficiaries during mutual crop sharing and also can draw the day to day working habits(Dessalegn Amsalu,20I0;PP.42-6).

Above all, farming alliance among the Gumuz and the neighboring highlanders became the bench mark for the beginning of experience sharing and transfer of working habits from the latter's to the former. Therefore, the Gumuz, who were the owners of the virgin lands but poor in both technical knowledge and farming by using the oxen drawn plough, could be able to imitate the knowledge of oxen drawn farming from the newly arrived people, particularly from the Agaws(Informants: Lukundi Hatse, Asheber Woldu; Dessalegn, Ibid). Since then, the Gumuz people tried to change digging tools by oxen drawn plough and also tried to replace living through hunting and gathering by domestication of plants and animals, in which also known as the beginning of agriculture(Informants: Lukundi Hatse, Asheber Woldu;Dessalegn Ibid).

According to Dessalegn, there are two types of animal rearing alliances in and around the Gumuz lands of Matakal in between the Gumuz and the neighboring Agaws in particular, where it was called "cross border seasonal" cattle migration and permanent residence rearing. However, as their interaction is sometimes smooth and another times also hostile, there is killing, hating and plundering of one's property around the Gumuz lands. In spite of their hostile and smooth relationships, there are high socio-cultural, economic, ecological and political interactions among themselves (Dessalegn, 20I0; Informants: Qanaw Gobbana.Lukundi Hatse).

\subsection{Local Strategies for Peace Building Process}

The Gumuz have maintained distinct types of traditional conflict resolution mechanisms with each ethnic group who inhabited in the region. For instance, Michu and Luba Bassa with the Oromo, Mangima within Gumuz communities, Harma Hodha with the Shinasha, Wudaj with the Awi and Wadaj strategy with the Amhara. In spite of this spiral, of conflicts have been affecting the region's peace and stability. Hence, the issue of conflict resolution needs immediate attention as a precondition for any sustainable development and food security in the region( Informants: Qanaw Gobbana.Lukundi Hatse).

The relationship in between Awi and Gumuz is likewise characterized by both hostile and friendly. The latter were indirectly ruled by the local chiefs appointed by the state from the former. Thus, the former was said to have raided the latter continuously for the slaves. Besides, the Awi pushed them away to the peripheries and exploited them and looted their property by using the land $\operatorname{tax}$ as the pretext. However, they both have tried to develop the socio-cultural, economic and political interactions beginning from the eve of the I99I democratic revolution in the country (Informants: Admas Yismaw, Asheber Woldu, Qanaw Gobbana).

Through time, the Gumuz and other ethnic communities in Mätäkäl were said to have solved their periodic skirmishes by using the traditional peace building mechanism, locally known as Michu. It is the traditional basis for conflict resolution among the ethnic groups living in and around Mätäkäl either together with the Gumuz or by neighboring them. Thus, Michu played a per-amount role in mitigating ethnic conflicts arose either individually or in a group form. Therefore, this traditional peacemaking institution has laid the foundation for cultural tolerance among ethnic diversity in countries like Ethiopia with multi-national state (Ibid).

Besides, the traditional institution also brought about extra mutual benefits among different ethnic communities in Mätäkäl. Gradually, this conflict resolution strategy was transformed from conflict solving to cultural assimilation and interethnic interaction. Immediately following the post I99I revolution in Ethiopia, the government allowed a chance of selfdetermination to the nations and nationalities throughout the country(Informants: Maku, Yeshiwas,Assefa) . By using the opportunity, multi-ethnic communities throughout the country started to discuss freely, to participate genuinely, and to advance their equality, to appreciate good governance, to fight against poverty, disease, terrorism, corruptions and then, stand for advancing peace and order in the region in $\operatorname{particular}($ Ibid).

\section{Conclusion}

The Gumuz are one of the Koman branches of the Ethiopian Nilo-Saharan language speaking people located along the Blue Nile River Valley and its tributaries .Originally, they used to live in the region of Mätäkäl up to the shores of Lake Tana, as far as the low land areas of Awi Zone, in the Amhara National Regional State. These people are apparently pressurized to move further west wards by the highland inhabitants. Their peripheral survival demonstrated a long process of competition from competing overlords in the Sudan and Ethiopia. Wherever threats increased from the nearby inhabitants and other settling and re-settling highlanders, they retreated into the open lowlands and malaria infested areas of the remotest far west.

The Gumuz inhabited areas of Matakal is endowed with very crucial natural resources such as the most valuable minerals, endemic and non-endemic wild animals and bird species. The region has hosted by diverse ethnic groups who came to the region in different times for the sake of fulfilling their daily needs. Among the ethnic groups, the following are worth 
mentioned. The Gumuz, Awi,Śinaśa, Oromo, Amhara and other settler communities who flocked from different areas of the country in to the region.

In the case of the socio-cultural ,religion, economic and political interactions, the Gumuz are animistic, who worship in the "spirits" of certain rocks, trees, and animals for good health, good crops, good luck, and protection. Rebba is their "supreme god to mean all." However, in the current situation, there are certain Gumuz community who accepted Catholicism and Protestantism. The Gumuz firmly believe that if a woman drinks milk, she will go bald, and if a man eats cabbage, he will be lazy. If a woman eats porridge while she is making it, they believe she or her husband will become ill. As the marriage style is concerned, Polygamous marriage system among Gumuz and marriage arrangement by parents without the consents of the woman is one of the main causes of women subordination.

Among the marriage systems exercised by the Gumuz community, exchange marriage system is one of the dominant marriage type that denies the right of the girl and done without the interest and willingness of both women (the bride and exchange one). Inheritance marriage is also another subordinating factor in which the household properties and investment kept only in the male line. In such marriage arrangements a widowed is not in a position to refuse the wish and interest of her husband's family. Thus, any form of refusal on the female side may lead to loss of any property including her children and put her in risk of unaccepted by the society.

Due to landlessness because of the land tenure system and the inability of the Muslims to own rist lands in these provinces, they were forced to move and settle in Mätäkäl. Population pressure and environmental degradation were equally pushing factors. Thus, because of the presence of abundant natural resources in the region, Mätäkäl attracted a huge number of the Amhara communities who flocked continuously and settled with the incorporation of the region since in the last decades of the nineteenth century. Since then, they took control of the western part of the region, today's Benishangul Gumuz National Regional State, in the form of settlers, tax assessing committee (supervisors), administrators, securing members, religious preachers and by using other simulations. Since then, they started devastations, raids, slavery, and whatever they like. Then reasonably, the Gumuz were the prime victims and the losers.

Although, there is generally a relative peace and stability in the region, local conflict in the form of either individual or group has continued for several years. The major causes of conflicts between the Gumuz and other ethnic communities include encroachment, alleged evil eye, abduction, adultery, murder, thieving, the question of land and other minor causes.

The Gumuz have maintained distinct types of traditional conflict resolution mechanisms with each ethnic group who inhabited in the region. For instance, Micu and Luba Bassa with the Oromo, Mangima within Gumuz communities, Harma Hodha with the Sinaśa, Wudaj with the Awi and Wadaj strategy with the Amhara. In spite of this spiral, of conflicts have been affecting the region's peace and stability. Hence, the issue of conflict resolution needs immediate attention as a precondition for any sustainable development and food security in the region.

The relationship between the highlanders and the Gumuz has been likewise characterized by both hostile and friendly. The latter were indirectly ruled by the local chiefs appointed by the state from the former. Thus, the former was said to have raided the latter continuously for the slaves. Besides, the highlanders pushed them away to the peripheries and exploited them and looted their property by using the land tax as the pretext. However, they both have tried to develop the socio-cultural, economic and political interactions beginning from the eve of the I99I democratic revolution in the country.

Through time, the Gumuz and other ethnic communities in Mätäkäl were said to have solved their periodic skirmishes by using the traditional peace building mechanism, locally known as Michu. It is the traditional basis for conflict resolution among the ethnic groups living in and around Mätäkäl either together with the Gumuz or by neighboring them. Thus, Michu played a per-amount role in mitigating ethnic conflicts arose either individually or in a group form. Therefore, this traditional peacemaking institution has laid the foundation for cultural tolerance among ethnic diversity in countries like Ethiopia with multi-national state.

\section{Conflict of Interests}

The author has not declared any forms of conflict of interests.

\section{References}

Periodicals, Documentary Electronic Sources and Reports

UNFPA. Bush Birthing Cuts Corners: The Case of Beniŝangul Gumuz.Asossa,20I4.

Fekadu Wamber, "Yé Gumuz béhéréséb açeir yé bahil zägäbä” (A brief cultural report of the Gumuz people, I998 Mätäkäl Zonal Agricultural Department Office Report. Asossa,20I4

Beniŝangul Gumuz Region Food Security Strategy Report, Beureau of Finance and Economic Development, Asossa, 2004.

${ }^{7}$ Rist, is a part of land which is hereditary in nature, which will be pass among the same blood line from generation to generation. 


\section{Unpublished Sources}

Thesis, Dessertations and Other Papers

Jira Mekuria. “AHistory of the Gumuz People of Metekel (I94I-I99I).”M.A.Thesis in History, Addis Ababa: Addis Ababa University, 2008.

Dessalegn Rahamato. "Resettlement and Indigenous Population of Metekel.”Paper Presented for the Institute of Development Research on Famine Experience and Resettlement in Ethiopia, Addis Ababa: Addis Ababa University,I988.

Bogale Aligaz. "Conflict Resolution among the Gumuz Communities: Mangima Institution in the Twentieth Century." M.A.Thesis in History.Bahir Dar : Bahir Dar University,20I3.

Berihun Mebratie. "Spontaneous Settlement and Interethnic Relations in Metekel, North Western Ethiopia.”M.A.Thesis in Sociology and Social Anthropology, Addis Ababa: Addis Ababa University, I999.

."The Past in the Present: The Dynamics of Identity and Otherness among the Gumuz of Ethiopia."Doctoral Thesis in Social Anthropology, Norwegian University of Science and Technology, Trondheim,2004.

Alemayehu Erkihun. "State and Ethnic Interaction in Agäw Meder and Mätäkäl: The Case of Awi and Gumuz in the Twentieth Century.” M.A.Thesis in History, Bahir Dar: Bahir Dar University, 2012.

Aysheshim Madfu. "Crime and Custom: With Reference to the Śanquilla Nationality.”Senior Essay in Law. Addis Ababa: Addis Ababa University, 1987.

Dessalegn Rahamato. "Resettlement and Indigenous Population of Metekel.”Paper Presented for the Institute of Development Research on Famine Experience and Resettlement in Ethiopia, Addis Ababa: Addis Ababa University,I988.

Tsegaye Morada. "Listening to their Silence? The Reaction of the Gumuz People against Large-Scale Land Acquisitions in Beniŝangul Gumuz Region.” Ethiopia: Asossa, 2013.

Wubat Engidayehu. "AHistory of Gojjam-Awi and Their Relations to Neighboring Gumuz People (I855-I99I)." M.A.Thesis in History, Mekelle: Mekelle University, 2012.

\section{Published Sources \\ Article}

Berihun Mebratie. "The Gumuz: Are they Shifting Cultivators? Proceedings of the Sixteen International Conferences of the Ethiopian Studies, Vol.2. Norway: Trondheim, 2009.

Tsega Endalew. "Conflict Resolution through Cultural Tolerance: Analysis of the Miḉu Institution in Mätäkäl Region, Ethiopia.” Social Science Report Series No.25, Addis Ababa: OSSREA,2002.

Wolde-Sellassie Abbute. "Nature, Culture and Encroachment: Indigenous Resource Management of Gumuz under Stress in Metekel, North Western Ethiopia." Proceedings of the XIV th International Conference of the Ethiopian Studies, Institute of Ethiopian Studies: Addis Ababa University, 2002.

\section{Books}

Bender, Lionel. The Ethiopian Nilo-Saharans. Addis Ababa: Addis Ababa University Press, 1975.

Central Statistics Agency.Population and Census .Addis Ababa: Statistics Agency, 2007.

Dessalegn Amsalu. The Nature of Awi-Gumuz Relations: The Dynamics of Ethncity in Ethiopia. USA: VDM Verlag , 2010.

Tsega Endalew. Inter-Ethnic Relations on Frontier: Metekel (Ethiopia), I898-1991. Germany: Wiesbaden, 2006.

Wolde Sellassie Abbute. Gumuz and Highland Resettlers: Differing Strategies of Livelihood and Ethnic Relations in Metekel, North Western Ethiopia (USA: Die Deutche Biblio thek, I984 . Indigenous Livelihood Strategies and Resource Management Systems in Beniŝangul Gumuz. Addis Ababa: Oxfam Canada,2004.

\section{Copyrights}

Copyright for this article is retained by the author(s), with first publication rights granted to the journal. This is an open-access article distributed under the terms and conditions of the Creative Commons Attribution license (http://creativecommons.org/licenses/by/4.0/). 